\title{
Governance Solutions to the Tragedy of the Commons That Marine Plastics Have Become
}

\section{OPEN ACCESS}

Edited by:

Francois Galgani,

Institut Français de Recherche pour

l'Exploitation de la Mer (IFREMER),

France

Reviewed by:

Thomais Vlachogianni,

Mediterranean Information Office for Environment Culture and Sustainable

Development, Greece

Christos loakeimidis,

United Nations Environment

Programme Mediterranean Action Plan, Greece

*Correspondence: Britta D. Hardesty denise.hardesty@csiro.au

Specialty section:

This article was submitted to Marine Pollution

a section of the journal Frontiers in Marine Science

Received: 27 March 2018 Accepted: 30 May 2018 Published: 19 June 2018

Citation:

Vince $J$ and Hardesty BD (2018) Governance Solutions to the Tragedy of the Commons That Marine Plastics Have Become. Front. Mar. Sci. 5:214. doi: 10.3389/fmars.2018.00214

\author{
Joanna Vince ${ }^{1}$ and Britta D. Hardesty ${ }^{2 *}$ \\ ${ }^{1}$ School of Social Sciences, University of Tasmania, Launceston, TAS, Australia, ${ }^{2}$ Commonwealth Scientific and Industrial \\ Research Organisation, Canberra, ACT, Australia
}

Plastic pollution has become the new millennium's tragedy of the commons. This is particularly true with the marine debris plastic pollution issue, which has seen significant global interest recently. There is long-standing acknowledgment of the difficulty in managing the commons, with regulations, economic and market based instruments and community-based solutions all having a role to play. We review the global plastic pollution issue in the context of governance and policy, providing examples of successes, opportunities and levers for change. We discuss the role of regulation, public perception and social license to operate (SLO) in managing waste that enters the ocean. We argue that while plastic pollution is a tragedy, there are many opportunities for reduction, management, and changes to the global community's relationship with plastic.

Keywords: marine debris, microplastic, plastic pollution, social license, tragedy of the commons, waste mismanagement

\section{INTRODUCTION}

Since Hardin (1968) published his seminal piece outlining the difficulties with managing the commons, the oceans have been identified as a common pool resource that are susceptible to degradation and over exploitation. In our modern "plastic era" plastic debris in the marine environment has become as much a "commons" and a "tragedy" as is the ocean itself. It is now estimated that 8,300 metric tons of plastic have been produced by humans since the 1950s and if these rates continue, 12,000 metric tons will be in the natural environment by 2050 (Geyer et al., 2017). Plastics have been found in even the most remote parts of the Arctic and Antarctic oceans and microplastics in particular (particles $\leq 5 \mathrm{~mm}$ in size, see Masura et al., 2015) have been identified in every marine habitat (Ivar do Sul and Costa, 2014).

Plastic pollution, and indeed, littering is not a new phenomenon. Plastics have been used since World War II (Joyner and Frew, 1991), with plastic production growing exponentially for an array of polymer types since the 1950s (Andrady and Neal, 2009). However, plastic pollution did not become a concern to the global community until the 1960s. Similarly to other pollutant problems of the time, it has become increasingly recognized as a potential significant detriment to the health of ocean; similarly to how DDT was identified by Rachel Carson in "Silent Spring" (Carson, 2002; Worm, 2015).

Marine litter has been defined by the United Nations Environment as "any persistent, manufactured or processed solid material discarded, disposed of or abandoned in the marine and coastal environment. Marine litter consists of items that have been made or used by people and deliberately discarded into the sea or rivers or on beaches; brought indirectly to the sea with rivers, sewage, storm water or winds; accidentally lost, including material lost at sea in bad weather (fishing gear, cargo); or deliberately left by people on beaches and shores)" (Jeftic et al., 2009). 
Litter, much of which is plastic, is found in the marine environment and ranges from large industrial containers to plastic bags, drink containers, cigarette butts, plastic fragments, manufactured plastic pellets (often called nurdles) (see Ogata et al., 2009) and numerous other consumer items. This anthropogenic litter, interacts not only with marine megafauna such as seabirds (Spear et al., 1995; Wilcox et al., 2016, others), turtles (Schuyler et al., 2014 and references therein), marine mammals and fish (Davison and Asch, 2011; Choy and Drazen, 2013; Rochman et al., 2015 and others), but also with bivalves, lugworms, oysters and corals (Hall et al., 2015; Van Cauwenberghe et al., 2015). To date, the demonstrated impacts to wildlife have most frequently been documented and reported at the individual organism and sub-organismal levels (Rochman et al., 2016), with experts viewing entanglement, ingestion and chemical contamination as all having the potential for significant (e.g., lethal or sub-lethal) impacts to marine vertebrate fauna (Wilcox et al., 2016).

Microplastics are a specifically identified subset of marine pollution that is of increasing concern. They result from the breakdown of larger plastics and are also manufactured specifically for use in consumer goods (as microplastic beads). These small particles have high surface to volume ratios and can sorb environmental contaminants. Also, they are accessible to a wide array of marine organisms from the smallest (e.g., plankton) to the largest marine fauna (e.g., whales, fish, seabirds, and so on). Furthermore, as people eat filter-feedings marine delicacies such as shrimp, scallops, mussels and sea cucumbers, the relationship to human health and food security becomes an increasing concern (Ivar do Sul and Costa, 2014).

In addition to impacts on biodiversity, anthropogenic debris or litter has implications for aesthetics and economics, which are tightly intertwined (Hardesty et al., 2017). For example, after a heavy rainfall event which resulted in a significant increase in coastal debris loads in South Korea, revenue losses from tourism were estimated at \$29-37M USD (Jang et al., 2014). In coastal California, visitors are reported to travel longer distances to avoid beaches with more waste (Leggett et al., 2014), and in Brazil, a recent survey reports that $85 \%$ of beachgoers will avoid beaches with high litter loads ( $>15$ pieces per $\mathrm{m}^{2}$ ) (Krelling et al., 2017). This is also interesting in light of numerous reports (and anecdotal evidence) that beachgoers themselves can be a contributing source of debris (Santos et al., 2005).

Solutions to managing the tragedy of plastic pollution, as any commons, are multifaceted requiring a mixture of regulation, economic/market and community-based efforts (Feeny et al., 1990; Ostrom et al., 2002; Dietz et al., 2003). They range from local community efforts to global actions (Vince and Hardesty, 2016). Globally, the need to address the plastic problem is increasingly recognized with discussions on marine plastic pollution occurring at international fora such as the World Oceans Summit (2017) and at recent meetings of the top seven and top 20 global economies G7 and G20. Furthermore, a Ministerial Declaration "Toward a Pollution Free Planet" was adopted by consensus by the UN Environment Assembly (2017). While a new legally binding international agreement is urgently needed (Chen, 2015; Vince and Hardesty, 2016; Raubenheimer and McIlgorm, 2017; Worm et al., 2017), it will need to work in context with economic and biodiversity goals.

We discuss solutions to the marine plastic pollution issue, and we describe examples of successes, opportunities and levers for change. These can be achieved in addition to regulatory measures including community's ability to give or withhold social license to operate (SLO) and self-regulatory measures in the private sector (through tools such as corporate or environmental social responsibility policies). We argue that marine plastic pollution is a tragedy of the commons. However, it is a tragedy that can be reversed, and one where communities both local and global can successfully contribute to change.

\section{REGULATORY MEASURES}

\section{Global Approaches}

Three quarters or more of waste that ends up in the ocean comes from land-based sources (Derraik, 2002; Hardesty et al., 2014; Jambeck et al., 2015). Accordingly, management of this waste needs support not only on the global scale, but also at national and local levels. There is a large gap in international hard law specifically dealing with land based plastic marine pollution. The United Nations Law of the Sea Convention (UNCLOS) Part XII (articles 192-237) is dedicated to the protection and preservation of the marine environment. States are required to take all measures "that are necessary to prevent, reduce and control pollution of the marine environment from any source, using for this purpose the best practicable means at their disposal and in accordance with their capabilities, and they shall endeavor to harmonize their policies in this connection"(Article 194). It also sets out the responsibilities of states and necessary measures they need to undertake to minimize pollution their own and other states' jurisdictions. While UNCLOS recognizes the differences between sea based and land based pollution, it does not address the type of pollutants and technical rules in great detail (Palassis, 2011). States are required to adopt their own laws and regulations that address marine pollution.

In the case of ship-sourced pollution, the International Maritime Organization (IMO) takes responsibility for the 1972 Convention on the Prevention of Marine Pollution by Dumping of Wastes and Other Matter (London Dumping Convention) and the 1973 International Convention for the Prevention of Pollution from Ships (MARPOL) (Joyner and Frew, 1991). Annex V of MARPOL (entered into force in 2013 with further revisions in March 2018) is particularly important with regard to anthropogenic debris as it prohibits the disposal of plastics anywhere at sea. Ships are required to dispose of their waste at land based wasted facilities. MARPOL Annex V "requires states to provide reception facilities for garbage at ports and terminals, and to present a list of these facilities to the IMO." Compliance, however, remains a significant issue and states around the world are in varying phases of implementing their domestic policies that reflect this regulation (Ryan, 2015).

To date, soft law has dominated efforts to address plastic marine debris and it has had a discernible influence in some areas. For instance, the UN Conference on the Environment and Development's Agenda 21 encourages integrated, precautionary 
and anticipatory marine environmental protection (UN, 1992). It sets out an approach to addressing damaging impacts from air, land and water; recycling; sewerage treatment; and the prevention, reduction and control of ship sourced pollution (Palassis, 2011). The Conference of the Parties to the Convention on Biological Diversity (COP CBD) Scientific and Technical Advisory Panel of the Global Environment Facility adopted Decision XI/18 at the 11th Meeting (2012) which addresses the impacts of marine debris on marine and coastal biodiversity. The Parties also agreed upon a Strategic Plan for Biodiversity (20112020) that includes Aichi Biodiversity Targets. Target 8 states that a goal that "by 2020, pollution, including from excess nutrients, has been brought to levels that are not detrimental to ecosystem function and biodiversity." Monitoring measures to assess such targets, however, will need to be established appropriately to assess whether targets are met.

The United Nations Environment Program (UNEP) has also addressed marine pollution through specific guidelines (UNEP, 2009a,b) that include the Guidelines On the Survey And Monitoring Of Marine Litter (2009), Guidelines On The Use Of Market-Based And Economic Instruments (2009) and Marine Litter a Global Challenge (Jeftic et al., 2009). The latter report provides a number of recommendations for the 13 participating Regional Seas programmes including, inter alia, the development of a Regional Action Plan or strategy to deal with marine pollution; mitigation should be global but coordinated at the regional level and implemented at the national level; National Plans of Action that draw on existing legislation; and the coordination of UN organizations working on the marine litter problem (see regional approaches, below).

The Honolulu Strategy (UNEP, 2012) was adopted by participants of the Fifth International Marine Debris Conference (5IMDC). The Honolulu Strategy is a volunteer-supported, global strategy to reduce marine debris. Also in 2012, the UNEP Global Partnership of Marine Litter (GPML) was announced. GPML is part of the UN Environment Global Programme of Action for the Protection of the Marine Environment from Landbased Activity (GPA). This global partnership is a coordinating forum for stakeholders at all levels working on marine debris prevention and management. It is generally agreed on a global level that a coordinated effort is required by governments, the private sector and civil society to reduce and prevent plastic pollution entering the ocean (Global Ocean Commission, 2014). This was further highlighted by The G7 (consisting of Canada, France, Germany, Italy, Japan, the United Kingdom and the United States) which released an Action Plan to Combat Marine Litter in June 2015. This Action Plan included land and sea-based priorities to reduce marine debris.

Outcomes of the G7 and G20 meetings include Action Plans on Marine Litter and the 2017 UNEP launching of the CleanSeas Campaign (Mendenhall, in press). The Joint Group of Experts on the Scientific Aspects of Marine Environmental Protection (GESAMP) has supported multiple working groups on various components of plastics and microplastics in the ocean (GESAMP W40 - see http://www.gesamp.org/work/groups/40) which is managed by the United Nations Educational, Scientific and Cultural Organization-Intergovernmental Oceanographic Commission (UNESCO-IOC) and UNEP. The key objective for the current working group (2017-2018 period) is to develop guidelines for the terminology and methodologies for sampling and analysis of macro and micro plastics, which has long been identified as a key gap or challenge.

There has also been a recent focus on global plastic pollution in the Sustainability Development Goals (SDG), in particular, SDG14.1, which focuses on life below water. Substantial efforts have been made to implement these sustainability development goals through the Oceans Conferences held in 2017 and 2018. The 2017 meeting resulted in the creation of the Communities of Ocean Action that included representation from governments, non-government organizations (NGOs) and civil society groups (Haward, 2018). In December 2017, the UN Environment Assembly passed a non-binding resolution on marine litter and microplastics that encouraged member states to "develop integrated and source-to-sea approaches to combat marine litter and microplastics from all sources" and it recognized "that private sector and civil society, including non-governmental organizations, can contribute significantly to prevent and reduce marine litter and microplastics" (resolution UNEP/EA.3/L.20).

There are numerous efforts afoot at international, national and sub-national levels to collate information about existing efforts, to engage institutions, governments, and other bodies to incorporate sustainability measures aimed at reducing plastic pollution. Furthermore, there is an expanding interest in the circular economy of plastic. The circular economy in the plastic context aims to shift from a produce, use, dispose approach to a design, use, re-design/re-use approach. Furthermore, the circular economy encourages supply chain investment opportunities to address marine plastic pollution-before such waste makes it to the ocean (MacArthur et al., 2016; Moss et al., 2017).

A new legally binding global instrument will take time and is complex as it requires agreement from multiple partners with varying capacity, resources and waste management infrastructure capability. It will also benefit from a holistic, integrated approach that combines community and economic/market instruments to help provide solutions to the marine litter issue. In the meantime, the initiatives mentioned above are recognized for providing a broad framework for addressing the plastics pollution issue at the large scale (see Figure 1).

\section{Regional Approaches}

Regions around the world are also addressing marine plastic pollution at appropriate regional geographic scales. Regional approaches occur between the national and global efforts (as seen on the continuum in Figure 1). For example, regional fisheries organizations have provisions to address sea and ship based pollution. The Commission for the Conservation of Antarctic Marine Living Resources (CCAMLR) also has a mandatory requirement for fishers in the Southern Ocean to report gear loss to the Scientific Committee (CCAMLR, 2015). The activities that can cause pollution are relatively well monitored in the Southern Ocean. However, not all areas of ocean are well managed and compliance remains an issue. Plastic pollution is a transboundary challenge, and when it occurs in Areas Beyond National Jurisdiction (ABNJ) the issue of responsibility is particularly problematic, particularly when it comes to removal of plastic debris (Vince and Hardesty, 2016). 


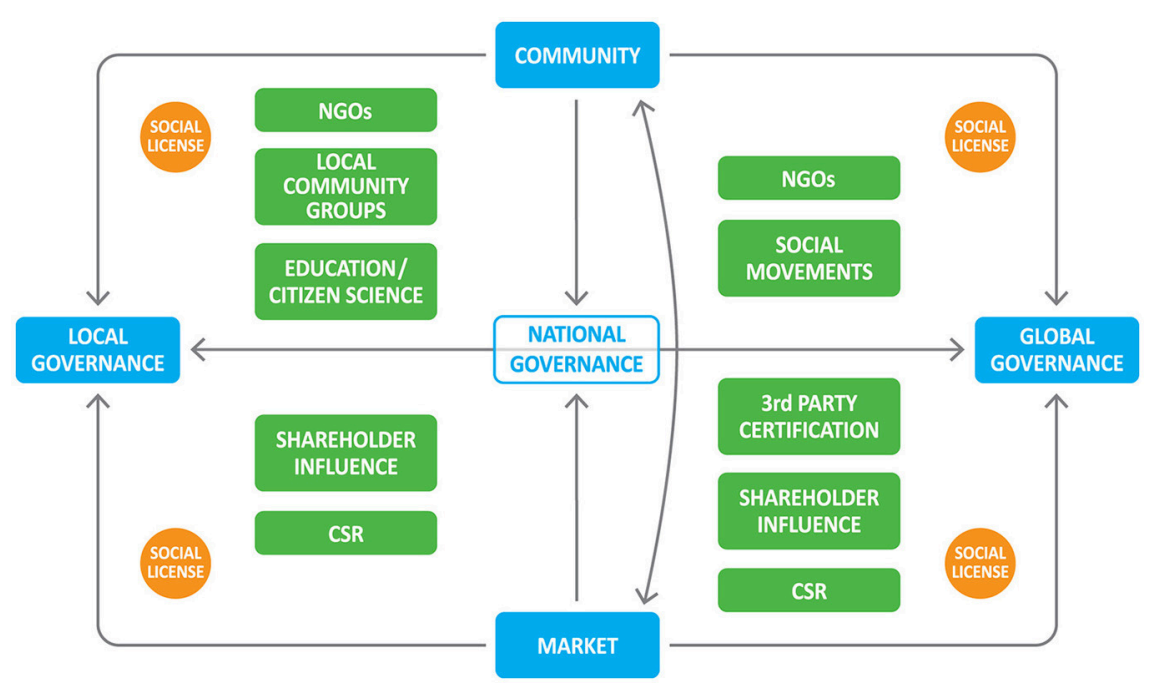

FIGURE 1 | A holistic governance approach to the reduction of plastic marine litter.

Around the world there are a number of regional seas conventions and action plans underway to combat plastic pollution. For example, there is a Regional Action Plan on Marine Litter management (RAPMaLi) for the wider Caribbean Region. This plan addresses litter issues in the wider Caribbean basin, supported by the UN's Caribbean Environment Programme (http://www.cep.unep.org/regional-action-plan-on-marine-

litter-management-rapmali-for-the-wider-caribbean-region). Similarly, the Northwest Pacific Action Plan (NOWPAP; www. nowpap.org) contributes to the global action program that aims to protect the marine environment from land-based activities in the Northwest Pacific Region. NOWPAP has developed regional activity centers, including coastal environment assessment and emergency preparedness regional centers to address plastic pollution and other environmental issues within the region.

Within Europe the pollution issue is being addressed through Regional Sea Conventions-the Barcelona Convention, the Bucharest Convention, the HELCOM Convention and the Convention for the Protection of the Marine Environment of the North-East Atlantic (OSPAR). In 1972, for the first time all sources of pollution were recognized through the Helsinki Convention on the Protection of the Marine Environment of the Baltic Sea Area (the HELCOM Convention) (adopted in 1992). In 2015, a Regional Action Plan for Marine Litter in the Baltic Sea was adopted by nine coastal Baltic Sea states who are signatories of HELCOM (HELCOM, 2015).

The Convention for the Protection of the Marine Environment and Coastal Region of the Mediterranean (the Barcelona Convention) (initiated in 1976 and reviewed in 1995) addresses pollution from land and sea based sources. In 2013, the Mediterranean countries adopted the Regional Plan for Marine Litter Management in the Mediterranean of the Barcelona Convention-the first legally binding regional plan for marine litter management at European Regional Seas Level. Its signatories adopted the Mediterranean Action Plan which was one of UNEP's first regions in the Regional Seas Programme.
In 2016 UN Environment launched the ambitious Integrated Monitoring and Assessment Programme (IMAP) which aims to enable a " quantitative, integrated analysis of the state of the marine and coastal environment, covering pollution and marine litter, biodiversity, non-indigenous species, coast, and hydrography, based on common regional indicators, targets and Good Environmental Status descriptions." (http://web.unep.org website; accessed 20 May 2018).

The OSPAR Commission also has a Regional Action and implementation plan that focusses on key areas that include inter alia port reception facilities, fishing for litter, education and outreach and reduction of single use items (https://www.ospar. org/documents? $\mathrm{v}=34422$ ). OSPAR has developed consistent data collection approaches for marine litter monitoring and data reporting for the last several years (https://www.ospar.org/ work-areas/eiha/marine-litter). The Black Sea Region, under the auspices of the Bucharest Convention, is the last region which is yet to develop an Action Plan and when implemented, will complete the region's efforts in having regional action plans to combat marine pollution.

The Marine Strategy Framework Directive (MSFD), adopted by European Union (EU) member states in 2008, identifies marine litter as one of the descriptors of Good Environmental Status. The MSFD requires EU Member States to ensure that, by 2020 , "properties and quantities of marine litter do not cause harm to the coastal and marine environment." The key measures toward this end-reflected within the European Strategy for Plastics in a Circular Economy-include measures against single use plastics and fishing gear; restrictions related to the use of microplastics in products or measures against microplastics generated during the life cycle of products; measures to reduce marine litter from ships, including fishing vessels and recreational craft (http://ec.europa.eu/environment/marine/ good-environmental-status/descriptor-10/index_en.htm).

While we cannot include all regional approaches here, those described above provide relevant examples of significant steps 
being undertaken at regional levels around the world. It is relevant to note that Small Island Developing States (SIDS) are also becoming more deeply engaged in the marine pollution issue. This is a significant issue for SIDS, particularly because resources and infrastructure for waste disposal are inadequate in many of these developing countries. The Secretariat of the Pacific Regional Environment Program (SPREP) is now a regional node of marine litter prevention, supported by the GPML. The Pacific Ocean Pollution Prevention Programme (PACOL) Strategy and Work Plans document was released by SPREP and the IMO in 2015. The recommendations will be implemented through a bottom up approach which can be a time-intensive process. We acknowledge that regional oceans governance in the South Pacific is difficult to achieve (Vince et al., 2017) and the tragedy of the commons through plastic pollution adds another layer of complexity to already stretched resources in marine-and waste-management which may be particularly difficult for many small island nations.

\section{National Approaches}

While global decision making can direct national incentives, national-level policy actions are the mechanisms for steering action. Numerous nations around the world are addressing plastic pollution in various significant ways that we are unable to cover in depth here. However, efforts in developing countries such as Indonesia, Ghana and Kenya highlight the significance of this issue and its increasing recognition as an issue of concern, and legislation in New Zealand and the United States demonstrate that incentives can prove successful in reducing waste mismanagement.

In 2017, the coordinating Ministry of Maritime Affairs for the Republic of Indonesia, recently cited as one of the countries with the most significant waste mismanagement issues resulting in plastic pollution in the ocean (Jambeck et al., 2015), released Indonesia's Plan of Action on Marine Plastic Debris for 2017-2025. The Plan includes the five components of improving behavioral change, reducing land-and sea-based leakage, reducing plastics production and use, and enhancing funding mechanisms, policy reform and legislation enforcement. Although in its infancy, this Plan has already made an impact on reducing marine litter through community efforts that have been assisted and coordinated by government (Lasut et al., 2018). The Kenya government has recently passed legislation that prohibits the importing, making, or selling plastic bags. Any offenses will be punishable by fines of up to US\$40,000 (or up to 4 years in jail, ABC News, 2017). This may be viewed as a success story, and as a story of caution. The government is taking the plastic issue seriously, however, such sanctions can result in adverse effects in the community. The Waste and Environment Association of Kenya have opposed the ban on the basis that it will cost thousands of jobs (Xinhuanet, 2017). What seem like straightforward solutions are often complex, with myriad factors to consider.

In 2002, the government of Bangladesh was the first to ban plastic bags due to flooding caused by blocked stormwater drains (Dauvergne, 2018). Similarly, in 2015 in Ghana, plastic waste blocked drains and caused flooding that resulted in approximately 150 human deaths (Jambeck et al., in press).
The initial response was to ban plastics in a similar effort to that undertaken in Kenya, though this has been delayed. Officials of Ghana have recognized that policy responses need to be made through collective decision making with the participation of a range of stakeholders. While a National Plastic Management Policy is being developed, the country is focusing on innovative methods to solve the plastic pollution issue rather than through bans on particular products (see http://www. ghananewsagency.org/science/-ghana-is-not-ready-to-ban-

plastics-now \$-\$126770; http://mesti.gov.gh/mesti-embracesinnovative-use-plastic-waste/). To date, a large number of countries have introduced taxes, bans or restrictions on the use of plastic bags. In some countries, such as the United States of America and Australia, however, legislation has typically been implemented at a state-based level rather than through national approaches (Xanthos and Walker, 2017).

Other national measures to reduce (micro) plastic pollution from entering the ocean's waterways include New Zealand's plastic microbeads ban which is scheduled to come into effect in June 2018. Under section 23 of the Waste Minimisation Act 2008, wash off cosmetics (including body exfoliants and toothpastes and abrasive cleansing products) will be forbidden. In 2015, thenpresident Barak Obama signed the Microbead-Free Waters Act of 2015 into law within the United States of America. The law bans plastic microbeads in both personal care and cosmetic products and aims to stop the introduction of plastic microbeads into lakes, coastal areas and the ocean. However, the ban did not come to full effect until January 2018 revealing that implementation takes time (Stoett and Vince, 2018). Other countries that have pursued similar microbead bans or restrictions include Canada, Finland, France, Iceland, Ireland, Luxenburg, Norway, Sweden and the UK (Dauvergne, 2018).

\section{COMMUNITY-BASED MEASURES}

Governance solutions can also come from communities. Dietz et al. (2003) reported that effective commons governance is achieved when communities communicate effectively. Through communication, communities become involved in strong social networks and increase their social capital. This results in a decrease in monitoring of behavior and increases compliance. They also found that the tragedy of the commons can be overturned not only by regulation and marketbased mechanisms but also through adaptive governance strategies (Dietz et al., 2003). Although regulation and market approaches do manage resources successfully, the socioeconomic environment contributes to the degree of this success (Feeny et al., 1990). Furthermore, public opinion and good will is a key component to driving change.

Strength to create social change (and SLO) can be found in communities and other non-state actors. For example, there has been a swell in grass root efforts, such as those initiated by the global \#breakfreefromplastic movement which was launched in September 2016 (www.breakfreefromplastic.org). Since then, more than 1,000 non-governmental organizations from across the world have joined the movement demanding massive reductions in single-use plastics and to encourage new lasting solutions to plastic pollution. The organizations involved in 
the movement share the common values of environmental protection and social justice. This in turn helps guide their work at the community level while representing a global, unified vision through the \#breakfreefromplastic campaign. Movement members deliver campaigns that help avoid the plastics crisis from worsening. Some of these campaigns include working with local governments to implement zero waste programs, and exposing the role of companies in promoting and perpetuating the use of non-recyclable packaging (Von Hernandez, pers. comm. 4 Dec 2017). Another example is "Plastic Free July" (http://www.plasticfreejuly.org/). Started by a local government organization (Western Metropolitan Regional Council) in Western Australia in 2011, Plastic Free July is a campaign to nudge citizens into changing their consumer behavior in favor of avoiding single-use plastics. Individuals, schools, and organizations pledge to refuse single-use plastic during a single month (or week or day). The focus is on solutions and providing a toolbox in which participants can select appropriate measures for themselves (or their institutions). To date, more than 2 million people have participated in the event, which supports networking, storytelling and collaborative approaches to the challenge of single-use plastics in society (R. Prince-Ruiz, pers. comm., 1 Dec 2017).

There are many situations where communities have the capacity for self-management and it makes administrative and economic sense to include them in decision making in resource management (Feeny et al., 1990). Bye Bye Plastic Bags is one example (see http://www.byebyeplasticbags.org/) of a recent, successful community-based campaign aimed at reducing single use plastics, which has been driven by a change in public perception. This social initiative is driven by youth in Bali, Indonesia. Their community-based campaign aims to reduce single use plastic bags and has become a well-known international movement which focuses on education, joint messaging and youth empowerment. Shared governance between the community and the state, along with self-management (or co-management) "can capitalize on the local knowledge and long-term self-interest of users, while providing for coordination with relevant uses and users over a wide geographic scope at potentially lower transaction (rule-enforcement) cost" (Feeny et al., 1990). Large scale co-management, where communities drive the solution and share responsibilities with regulatory bodies, is one of the many means of combatting the plastic marine pollution problem. Such an approach, similar to the 1987 Montreal Protocol, would be a practical option internationally to help resolve this transboundary problem.

Education is also a key to strengthening community support and understanding of the impact of plastic on the marine environment. Supported by the United Nations, the GPML has sponsored numerous projects aimed to increase understanding of losses and movement of debris in the marine environment. These efforts have aimed to increase educational and public awareness through the development of a Massive Online Open Course (MOOC) on marine debris (https://www.ou.nl/ documents/40554/72652/MOOC_Marine_Litter_2017_leaflet. pdf/5d520cb2-b334-488e-826b-e19284916935) and to broaden the community engagement with the topic more generally.
Around the world there are hundreds of groups that have engaged with the public and with school children around marine litter. Whilst many organizations focus on an advocacy approach, others use the topic as an educational tool, developing content that addresses curriculum requirements (e.g., www.Teachwild. com.au). NOAA, for example, developed a "Turning the Tide on Trash" program in the United States (see www.marinedebris. noaa.gov for details); The University of California at Davis has developed a marine debris lesson, which includes analysis of debris on university campuses; and the Plastic Pollution Coalition (http://www.plasticpollutioncoalition.org/) has developed curriculum content for grades 7-12 that can be used in educational systems across the world. These organizations and dozens more make their content freely available on line. While there are a growing number of groups providing content and making materials available in different countries, a consistent message is the role and value of community engagement around an environmental issue that is relevant for people of all ages, from primary school children to senior citizens (see van der Velde et al., 2017 and references within).

\section{ECONOMIC/MARKET-BASED POLICY INSTRUMENTS AND THE IMPACT OF SOCIAL LICENSE}

The traditional form of governance through government and regulation has been unable to solve many of the world's "tragedy of the commons" environmental issues. Regulatory frameworks have often experienced difficulties and challenges with the implementation of sustainable, conservation measures, demonstrating that these regulatory measures alone cannot bring about the required change to effectively stop marine plastic pollution and land-based waste. However, when regulatory and market based incentives are combined, interesting developments can occur in the reduction of plastic use and pollution. A recent analysis highlighted the effectiveness of small incentives in reducing waste mismanagement in Australia and the United States. An incentive of as little as 5-10 cents through container deposit legislation (CDL) or cash for containers was effective in reducing beverage container waste (Schuyler et al., in press). The proportion of beverage containers found in coastal surveys from states with incentives was approximately $40 \%$ less than in states without incentives-and was consistent between the two countries (Schuyler et al., in press). Importantly, the reduction in beverage containers was greater in areas with lower socio-economic status, where debris loads are highest, providing strong evidence that incentives are particularly effective where incomes are lower (Schuyler et al., in press). This suggests that putting a price on plastic would likely be effective in terms of material recovery and would reduce loss rates to the environment. We already see this with material such as aluminum, steel and copper, as these materials are valuable and can be sold back into the market.

Market governance solutions are being developed and tested and indeed the economic cost of marine plastic pollution is another factor that needs to be considered as part of this solution 
(McIlgorm et al., 2011). For instance, there are efforts to clean up the well- known "Pacific Garbage Patch" located in both the East and West parts of the Pacific (Moore et al., 2001; Kaiser, 2010). However, such clean-up efforts are complex and unlikely to yield desired results. They are also addressing the "end of the pipe" rather than where efforts are likely prove successful (Rochman, 2016; Sherman and Van Sebille, 2016). Moreover the gap in international law addressing areas beyond national jurisdiction complicates the mitigation and removal of marine debris from these ABNJ areas. Finding solutions to removing marine debris or taking responsibility for it within the high seas from a governance and practical perspective adds another layer of complexity.

As a result, alternative tools and approaches, including external third party assessment and certification systems, have been developed to address perceived regulatory failure, including economic and community based management. These approaches (see link between the community and market in Figure 1) step outside state-based governance and address market and consumers directly through product certificates and ecolabels (Potts and Haward, 2007). Certification and labeling initiatives encourage industry best practices that influence shareholders and the market (such as sustainability labeling, green labeling, etc.). Moreover, certification and labeling can add another layer of legitimacy for community groups in providing their SLO. The legitimacy of third party certifiers can be removed at any time if the community decides not to accept the standards or organization. Certification schemes can therefore be considered "new markets of governance" through their organizational set up, consultancy services and contractual arrangements (Foley and Hébert, 2013). Although self-regulatory industry measures, policies and standards can also be effective in the plastics pollution issue, the opportunity to use third party certification organization as a regulatory measure has been little explored. Landon-Lane (2018) suggests that a "Plastics Stewardship Council" be enacted, based on the Marine Stewardship Council (MSC) model and we believe that this gap in governance will provide a unique and innovative way to address plastic pollution issues and to identify additional solutions to this problem.

Industry can also obtain social license through Corporate Social Responsibility (CSR) (Gjølberg, 2009). Corporate Social Responsibility is becoming an increasingly important priority for some companies involved in the development, distribution and life cycle of plastics. Although social license and CSR concepts are interrelated and overlap, there are key differences (Parsons and Moffat, 2014). SLO is an intangible, unwritten and impermanent social contract between industry and social groups (Parsons and Moffat, 2014). Through social license, communities and consumers can instigate changes to corporate policies and products (Morrison, 2014). Industry is, however, ultimately in control of its CSR policies and activities. According to Steurer (2013) "new governance and CSR are complementary concepts that both fundamentally reshape the roles of the public and the private sectors in similar directions." CSR can be driven by community support through social license or government regulation (Vince and Hardesty, 2016). Solutions to plastic pollution can be driven by willing industry and their use their
CSR policies to gain consumer confidence and to demonstrate their commitment to social and environmental issues. The Australian Packaging Covenant is but one co-regulatory nongovernment organization that partners government and industry with a goal of helping its industry-based signatories realize CSR opportunities.

The Secretariat of the Convention on Biological Diversity and the Scientific and Technical Advisory Panel - GEF (2012) has stated that "many companies now see packaging and plastics sustainability as part of broader corporate social responsibility, and negative brand image is becoming a major driving force which is being harnessed in the interests of improving packaging materials and technologies." This has been evidenced by a global Declaration for Solutions on Marine Litter which was developed and signed by industry plastics associations in 2011. Their aims include to "contribute to solutions by working in private-public partnerships aimed at preventing marine debris" and to promote science-based policies and enforcement of existing legislation. As of May 2016, 65 members from 34 countries have signed this Declaration and supported 260 projects (https://www.marinelittersolutions.com; accessed 4 Dec 2017). Industry is also being encouraged to take responsibility of the full life-cycle of the products they produce through Extended Producer Responsibility (EPR). This can be voluntarily driven by CSR policies, or in the case of many European nations EPR legislation has been enacted to reduce use and increase the reuse and recycling of plastics (Tibbetts, 2015; Worm et al., 2017). Changes to market and industry through EPR can result in an increase in Sustainable Development and Consumption production methods and address the SD goal 12-Responsible Consumption and Production (see https:// www.un.org/sustainabledevelopment/sustainable-consumptionproduction/).

The flow on effect of this in industry decision making is becoming evident. For example, Selfridges and Company, a UK based high end department store, initiated an intense oceans campaign that highlighted the impacts of single-use plastics on marine fauna. As part of their campaign, they no longer offer plastic bags in their stores, they aim to make communities and cities plastic water bottle free, and have a growing "Project Ocean" which targets consumer awareness with respect to micro-bead free products, sustainable seafood practices, and responsible purchasing. Community acceptance and trust offers stronger and higher levels of social license (Thomson and Boutilier, 2011; Parsons and Moffat, 2014), which may be apparent with the public's positive response to Selfridge's recent campaign.

Local communities in South Korea have used SLO to reduce mismanagement of polystyrene buoys (Lee et al., 2015). In this instance, their broader community views were represented in behavior change workshops with government and key stakeholders. A successful collaboration resulted in changes to national governmental policy-a significant SLO change that is particularly relevant when one considers that polystyrene buoys are the most abundant littered item found on Korea coastal beach surveys, and that they can account for $10 \%$ or more of marine debris nationwide (Lee et al., 2015). 
As most are aware, the media is a powerful, non-state actor that is capable of steering trust and social license (Vince and Haward, 2017). The media has the ability to influence community views and public perception and can affect how industry is scrutinized (Lester, 2016). Consequently, social license through social media has become a useful tool to bring about change (Boutilier et al., 2012). Recent campaigns $(2016,2017)$ by Greenpeace to target major industry beverage manufacturers are but one example (https://www.youtube.com/ watch?v=Q7Uxaw6YoRw) of the power of media to shape the conversation.

\section{USING SCIENCE TO INFORM THE "PLASTIC TRAGEDY"}

Industry has called on science to help drive marine litter policy (Vince and Hardesty, 2016), and indeed, there is a growing body of work on plastic pollution that is being used to inform the discussion and to underpin policy decisions at a multitude of levels. The regional, national and sub-national plans of action acknowledge the importance of evidence-based informational at relevant scales (as described above). Increasingly we see the inclusion of scientific experts in discussions on the threat posed by plastic pollution with bodies such as the Convention on Biological Diversity, the International Whaling Commission and the United Nations Environment. Similar conversations are being held at numerous local, state, national and fora in countries around the world.

Documentation of the ubiquity of plastics interactions between fauna and marine debris has exploded in recent years (see review by Gall and Thompson, 2015), with the number of peer-reviewed publications on the topic having quadrupled in the last few years alone (Dauvergne, 2018). Researchers have even identified what commonplace debris items are expected to have the most significant, deleterious impacts on major marine taxa and where major marine taxa are at the most significant risk (Wilcox et al., 2016). Other work has evaluated the effectiveness of various policies on mismanaged waste (Hardesty et al., 2017; Schuyler et al., in press; Willis et al., in press) visitors' response to local litter loads (Leggett et al., 2014) and the economic costs of marine debris pollution due to major weather events (Jang et al., 2014). Scientists have moved beyond providing evidence alone of the interactions between plastic and the environment, with the field having matured to address questions around what we know vs. what is believed (i.e., demonstrated evidence, opinions and public perception) (Rochman et al., 2015; Hardesty and Wilcox, 2017).

In an ideal world, a holistic approach to the governance of plastic pollution, science would underpin policy decision making so that decisions are based upon best available evidence. Policies, whether local, national, regional or global; communities that grant or withhold social license; and industries that ignore or respond through CSR efforts, all have been steered by scientific evidence that identifies and quantifies the extent of plastic pollution and its impacts on biodiversity, economics and society. However, there remains a gap between the way science is interpreted and translated into policy. This challenge is being continually addressed by researchers in the ocean and coastal science and governance space (Nursey-Bray et al., 2014; Rudd, 2015; Vince and Hardesty, 2016).

Currently, one of the emerging scientific questions that has significant potential to shift the conversation, is whether there is an impact on human health from plastics in the environment. This is of particular concern with respect to the potential for chemical contaminants in seafood consumed by humans-and the question points to a difficult-to-resolve knowledge gap. Applying a risk-based approach to the issue and considering the severity and certainty of particular events may prove particularly useful, particularly as we view through the management and impact lenses (see Hardesty and Wilcox, 2017, Figures 3, 4).

\section{CONCLUSION-A HOLISTIC APPROACH WILL BE MOST EFFECTIVE}

Arguably, the conversation about plastics and society is changing. There is an increasing focus on a circular economy approach which focuses on purposeful design to minimize waste, along with repurposing, reusing or recycling products (MacArthur et al., 2016). This is in sharp contrast to the linear economy approach of make, use, discard. A societal shift in the form of a new global social movement advocating awareness of plastic pollution is also emerging (Vince and Stoett, in press). This movement or shift from liner to circular is supported through scientific evidence, educational tools (Hartley et al., in press) and citizen science initiatives that foster a greater understanding of the vast task facing the global community to reduce plastic pollution. The individuals in this social movement are also consumers who by granting or withholding social license can steer policy changes, and more broadly alter societal attitudes and behaviors. The tragedy of the plastic commons is tractable and solvable. It will take a shared public will, effective policies and coordination to work effectively on global, regional, national, local and individual levels. We propose that a new global agreement could prove important in driving change. We also acknowledge that coming to such an agreement will be a difficult and time-consuming process, as there are a multitude of actors, drivers and competing agendas. In the meantime, regional, national and local governance approaches will provide some of the regulatory measures required to reduce plastic losses to the environment. The success of some of these regulatory measures will be reliant upon resources being available to develop and support the essential infrastructure. Industry-based solutions that utilize market/economic based initiatives will also prove useful-if they are environmentally and socially responsible. Profit and CSR policies can be mutually beneficial in driving such change in the market. Presumably, when all of these align, consumers will be supportive.

There is no "silver bullet" or single approach that will effectively resolve this complex environmental and societal challenge. Instead, an ever-changing variety of actions, activities, legislative and cooperative approaches will ultimately help resolve this tragedy of the commons that plastic pollution has become. 


\section{AUTHOR CONTRIBUTIONS}

All authors listed have made a substantial, direct and intellectual contribution to the work, and approved it for publication.

\section{REFERENCES}

ABC News (2017). Plastic Bag-Makers and Users Risk Jail, Fines as Kenya cracks Down on Pollution [Online]. Available online at: http://www.abc.net.au/ news/2017-08-28/kenya-imposes-worlds-toughest-law-against-plastic-bags/ 8850186 (Accessed August 28, 2017).

Andrady, A. L., and Neal, M. A. (2009). Applications and societal benefits of plastics. Philos. Trans. $R$ Soc. Lond. B Biol. Sci. 364, 1977-1984. doi: $10.1098 /$ rstb.2008.0304

Boutilier, R., Black, L., and Thomson, I. (2012). "From metaphor to management tool: how the social license to operate can stabilise the socio-political environment for business," in International Mine Management 2012 Proceedings (Melbourne, VIC), 227-237.

Carson, R. (2002). Silent Spring. New York, NY: Houghton Mifflin Harcourt.

CCAMLR (2015). "Conservation Measure 26-01 (2015)" in Adopted at Meeting: CCAMLR-XXXIV.

Chen, C.-L. (2015). "Regulation and management of marine litter" in Marine Anthropogenic Litter, eds M. Bergmann, L. Gutow, and M. Klages (Springer), 395-428.

Choy, C. A., and Drazen, J. C. (2013). Plastic for dinner? Observations of frequent debris ingestion by pelagic predatory fishes from the central North Pacific. Mar. Ecol. Prog. Series 485, 155-163. doi: 10.3354/meps 10342

Dauvergne, P. (2018). Why is the global governance of plastic failing the oceans? Global Environ Change 51, 22-31. doi: 10.1016/j.gloenvcha.2018.05.002

Davison, P., and Asch, R. G. (2011). Plastic ingestion by mesopelagic fishes in the North Pacific Subtropical Gyre. Mar. Ecology Progress Series 432, 173-180. doi: 10.3354/meps09142

Derraik, J. G. (2002). The pollution of the marine environment by plastic debris: a review. Mar. Poll. Bull. 44, 842-852. doi: 10.1016/S0025-326X(02)00220-5

Dietz, T., Ostrom, E., and Stern, P. C. (2003). The struggle to govern the commons. Science 302, 1907-1912. doi: 10.1126/science.1091015

Feeny, D., Berkes, F., McCay, B. J., and Acheson, J. M. (1990). The tragedy of the commons: twenty-two years later. Hum. Ecol. 18, 1-19. doi: $10.1007 /$ BF00889070

Foley, P., and Hébert, K. (2013). Alternative regimes of transnational environmental certification: governance, marketization, and place in Alaska's salmon fisheries. Environ. Plann. A 45, 2734-2751. doi: 10.1068/a45202

Gall, S. C., and Thompson, R. C. (2015). The impact of debris on marine life. Mar. Pollut. Bull. 92, 170-179. doi: 10.1016/j.marpolbul.2014.12.041

Geyer, R., Jambeck, J. R., and Law, K. L. (2017). Production, use, and fate of all plastics ever made. Sci. Adv. 3:e1700782. doi: 10.1126/sciadv.1700782

Global Ocean Commission (2014). From decline to Recovery: A Rescue Package for the Global Ocean. Global Ocean Commission.

Gjølberg, M. (2009). The origin of corporate social responsibility: global forces or national legacies? Socio-Econ. Rev. 7:605-637. doi: 10.1093/ser/mwp017

Hall, N., Berry, K., Rintoul, L., and Hoogenboom, M. (2015). Microplastic ingestion by scleractinian corals. Mar. Biol. 162, 725-732. doi: 10.1007/s00227-015-2619-7

Hardesty, B. D., Lawson, T., Velde, T., Lansdell, M., and Wilcox, C. (2017). Estimating quantities and sources of marine debris at a continental scale. Front. Ecol. Environ. 15, 18-25. doi: 10.1002/fee.1447

Hardesty, B., and Wilcox, C. (2017). A risk framework for tackling marine debris. Anal. Methods 9, 1429-1436. doi: 10.1039/C6AY02934E

Hardesty, B., Wilcox, C., Lawson, T., Lansdell, M., and van der Velde, T. (2014). Understanding the Effects of Marine Debris on Wildlife. A Final report to Earthwatch Australia (CSIRO).

Hardin, G. (1968). The Tragedy of the Commons. Science 162, 1243-1248. doi: $10.1126 /$ science.162.3859.1243

Hartley, B. L., Pahl, S., Holland, M., Alampei, I., Veiga, J. M., and Thompson, R. C. (in press). Turning the tide on trash: empowering

\section{FUNDING}

JV is supported by the University of Tasmania. BH is supported by CSIRO's Oceans and Atmosphere, the Oak Family Foundation and Schmidt Marine Technologies for this work.

european educators and school students to tackle marine litter. Mar. Policy. doi: 10.1016/j.marpol.2018.02.002

Haward, M. (2018). Plastic pollution of the world's seas and oceans as a contemporary challenge in ocean governance. Nat. Commun. 9:667. doi: 10.1038/s41467-018-03104-3

HELCOM (2015). Regional Action Plan for Marine Litter in the Baltic Sea. ed B. M. E. P. Commission. Helsinki: HELCOM.

Ivar do Sul, J.,A., and Costa, M.,F (2014). The present and future of microplastic pollution in the marine environment. Environ. Poll. 185, 352-364. doi: 10.1016/j.envpol.2013.10.036

Jambeck, J. R., Geyer, R., Wilcox, C., Siegler, T. R., Perryman, M., Andrady, A., et al. (2015). Plastic waste inputs from land into the ocean. Science 347, 768-771. doi: $10.1126 /$ science. 1260352

Jambeck, J., Hardesty, B. D., Brooks, A. L., Friend, T., Teleki, K., Fabres, J., et al. (in press). Challenges and emerging solutions to the land-based plastic waste issue in Africa. Mar. Policy. doi: 10.1016/j.marpol.2017.10.041

Jang, Y. C., Hong, S., Lee, J., Lee, M. J., and Shim, W. J. (2014). Estimation of lost tourism revenue in Geoje Island from the 2011 marine debris pollution event in South Korea. Mar. Pollut. Bull. 81, 49-54. doi: 10.1016/j.marpolbul.2014.02.021

Jeftic, L., Sheavly, S., and Adler, E. (2009). Marine Litter: a Global Challenge. Nairobi: UNEP.

Joyner, C. C., and Frew, S. (1991). Plastic pollution in the marine environment. Ocean Dev. Int. Law 22, 33-69. doi: 10.1080/00908329109545949

Kaiser, J. (2010). The dirt on ocean garbage patches. Science. 328:1506 doi: 10.1126/science.328.5985.1506

Krelling, A. P., Williams, A. T., and Turra, A. (2017). Differences in perception and reaction of tourist groups to beach marine debris that can influence a loss of tourism revenue in coastal areas. Mar. Policy 85, 87-99. doi: 10.1016/j.marpol.2017.08.021

Landon-Lane, M. (2018). Corporate social responsibility in marine plastic debris governance. Mar. Pollut. Bull. 127, 310-319. doi: 10.1016/j.marpolbul.2017.11.054

Lasut, M. T., Weber, M., Pangalila, F., Rumampuk, N. D. C., Rimper, J. R. T. S. L., Warouw, V., et al. (2018). "From coral triangle to trash triangle-how the hot spot of global marine biodiversity is threatened by plastic waste", in Proceedings of the International Conference on Microplastic Pollution in the Mediterranean Sea, eds M. Cocca, E. Di Pace, M. Errico, G. Gentile, A. Montarsolo, and R. Mossotti (Cham: Springer), 107-113.

Lee, J., Hong, S., Jang, Y. C., Lee, M. J., Kang, D., and Shim, W. J. (2015). Finding solutions for the styrofoam buoy debris problem through participatory workshops. Mar. Policy 51, 182-189. doi: 10.1016/j.marpol.2014. 08.008

Leggett, C. G., Scherer, N., Curry, M. S., Bailey, R., and Haab, T. C. (2014). Assessing the Economic Benefits of Reductions in Marine Debris: A Pilot Study of Beach Recreation in Orange County, California: Industrial Economics, Incorporated.

Lester, L. (2016). Media and social licence: on being publicly useful in the Tasmanian forests conflict. Forestry 89, 542-551. doi: 10.1093/forestry/cpw015

MacArthur, D., Waughray, D., and Stuchtey, M. (2016). "The New Plastics Economy, Rethinking the Future of Plastics," in World Economic Forum.

Masura, J., Baker, J. E., Foster, G., Arthur, C., and Herring, C. (2015). Laboratory Methods for the Analysis of Microplastics in the Marine Environment: Recommendations for Quantifying Synthetic particles in Waters and Sediments. US Department of Commerce, National Oceanic and Atmospheric Administration, National Ocean Service, NOAA Marine Debris Program.

McIlgorm, A., Campbell, H. F., and Rule, M. J. (2011). The economic cost and control of marine debris damage in the Asia-Pacific region. Ocean Coast. Manag. 54, 643-651. doi: 10.1016/j.ocecoaman.2011.05.007

Mendenhall, E. (in press). Oceans of plastic: a research agenda to propel policy development. Mar. Policy. doi: 10.1016/j.marpol.2018.05.005 
Moore, C. J., Moore, S. L., Leecaster, M. K., and Weisberg, S. B. (2001). A comparison of plastic and plankton in the North Pacific central gyre. Mar. Pollut. Bull. 42, 1297-1300. doi: 10.1016/S0025-326X(01)00114-X

Morrison, J. (2014). The Social License: How to Keep Your Organization Legitimate. Basingstoke: Springer.

Moss, E., Eidson, A., and Jambeck, J. (2017). Sea of Opportunity: Supply Chain Investment Opportunities to Address Marine Plastic Pollution. New York, NY: Encourage Capital on behalf of Vulcan, Inc.

Nursey-Bray, M. J., Vince, J., Scott, M., Haward, M., O’Toole, K., Smith, T., et al. (2014). Science into policy? Discourse, coastal management and knowledge. Environ. Sci. Policy 38, 107-119. doi: 10.1016/j.envsci.2013.10.010

Ogata, Y., Takada, H., Mizukawa, K., Hirai, H., Iwasa, S., Endo, S., et al. (2009). International pellet watch: global monitoring of persistent organic pollutants (POPs) in coastal waters. 1. Initial phase data on PCBs, DDTs, and HCHs. Mar. Poll. Bull. 58, 1437-1446. doi: 10.1016/j.marpolbul.2009.06.014

Ostrom, E. E., Dietz, T. E., Dolšak, N. E., Stern, P. C., Stonich, S. E., and Weber, E. U. (2002). The Drama of the Commons. Washington, DC: National Academy Press.

Palassis, S. (2011). "Marine pollution and environmental law," in Australian Coastal and Marine Law, eds R. Baird and D. Rothwell (Annandale, NSW: The Federation Press), 228-263.

Parsons, R., and Moffat, K. (2014). Constructing the meaning of social licence. Soc. Epistemol. 28, 340-363. doi: 10.1080/02691728.2014.922645

Potts, T., and Haward, M. (2007). Internation trade, eco-labelling, and sustainable fisheries - recent issues, concepts and practices. Environ. Dev. Sustain. 9, 91-106. doi: 10.1007/s10668-005-9006-3

Raubenheimer, K., and McIlgorm, A. (2017). Is the Montreal Protocol a model that can help solve the global marine plastic debris problem? Mar. Policy 81, 322-329. doi: 10.1016/j.marpol.2017.04.014

Rochman, C. M. (2016). Strategies for reducing ocean plastic debris should be diverse and guided by science. Environ. Res. Lett. 11:041001. doi: 10.1088/1748-9326/11/4/041001

Rochman, C. M., Browne, M. A., Underwood, A. J., van Franeker, J. A., Thompson, R. C., and Amaral-Zettler, L. A. (2016). The ecological impacts of marine debris: unraveling the demonstrated evidence from what is perceived. Ecology 97, 302-312. doi: 10.1890/14-2070.1

Rochman, C. M., Kross, S. M., Armstrong, J. B., Bogan, M. T., Darling, E. S., Green, S. J., et al. (2015). Scientific evidence supports a ban on microbeads. Environ. Sci. Technol. 49, 10759-10761. doi: 10.1021/acs.est.5b03909

Rudd, M. A. (2015). Scientists' framing of the ocean science-policy interface. Global Environ. Change 33, 44-60. doi: 10.1016/j.gloenvcha.2015.04.006

Ryan, P. G. (2015). "A brief history of marine litter research," in Marine Anthropogenic Litter, eds M. Bergmann, L. Gutow, and M. Klages (Heidelberg; New York, NY; Dordrecht; London: Springer International Publishing), 1-25.

Santos, I. R., Friedrich, A. C., Wallner-Kersanach, M., and Fillmann, G. (2005). Influence of socio-economic characteristics of beach users on litter generation. Ocean Coast. Manag. 48, 742-752. doi: 10.1016/j.ocecoaman.2005.08.006

Secretariat of the Convention on Biological Diversity and the Scientific and Technical Advisory Panel - GEF (2012). Impacts of Marine Debris on Biodiversity: Current Status and Potential Solutions. Montreal Technical Series No. 67, 61 .

Schuyler, Q., Hardesty, B. D., Lawson, T. J., Opie, K., and Wilcox, C. (in press). Economic incentives reduce plastic inputs to the ocean. Mar. Policy. doi: 10.1016/j.marpol.2018.02.009

Schuyler, Q., Hardesty, B. D., Wilcox, C., and Townsend, K. (2014). Global analysis of anthropogenic debris ingestion by sea turtles. Conserv. Biol. 28, 129-139. doi: $10.1111 /$ cobi.12126

Sherman, P., and Van Sebille, E. (2016). Modeling marine surface microplastic transport to assess optimal removal locations. Environ. Res. Lett. 11:014006. doi: 10.1088/1748-9326/11/1/014006

Spear, L. B., Ainley, D. G., and Ribic, C. A. (1995). Incidence of plastic in seabirds from the tropical pacific, 1984-1991: relation with distribution of species, sex, age, season, year and body weight. Mar. Environ. Res. 40, 123-146. doi: 10.1016/0141-1136(94)00140-K

Steurer, R. (2013). Disentangling governance: a synoptic view of regulation by government, business and civil society. Policy Sci. 46, 387-410. doi: 10.1007/s11077-013-9177-y

Stoett, P., and Vince, J. (2018). "Environmental justice and multi-level plastic governance: linking marine debris to climate change, biodiversity conservation, and human health," in The International Studies Association Annual Meeting (San Francisco, CA).

Thomson, I., and Boutilier, R. (2011). "The social license to operate," in SME Mining Engineering Handbook, ed P. Darling (Colorado, CO: Society for Mining, Metallurgy, and Exploration), 1779-1796.

Tibbetts, J. H. (2015). Managing marine plastic pollution: policy initiatives to address wayward waste. Environ. Health Perspect. 123:A90. doi: 10.1289/ehp.123-A90

UN (1992). "Chapter 17 in Conservation and management of resources for development concern (section)," Agenda 21: Programme of Action for Sustainable Development and the UNCED Proceedings, Oceana (New York, NY), Part 17.5.

UNEP (2009a). Guidelines on Survey and Monitoring of Marine Litter. Nairobi: UNEP.

UNEP (2009b). Guidelines on the Use of Market-Based and Economic Instruments. Nairobi: UNEP.

UNEP (2012). The Honolulu Strategy: A Global Framework for Prevention and Management of Marine Debris. Nairobi: UNEP.

Van Cauwenberghe, L., Claessens, M., Vandegehuchte, M. B., and Janssen, C. R. (2015). Microplastics are taken up by mussels (Mytilus edulis) and lugworms (Arenicola marina) living in natural habitats. Environ. Poll. 199, 10-17. doi: 10.1016/j.envpol.2015.01.008

van der Velde, T., Milton, D. A., Lawson, T., Wilcox, C., Lansdell, M., Davis, G., et al. (2017). Comparison of marine debris data collected by researchers and citizen scientists: is citizen science data worth the effort? Biol. Conserv. 208, 127-138. doi: 10.1016/j.biocon.2016.05.025

Vince, J., and Hardesty, B. D. (2016). Plastic pollution challenges in marine and coastal environments: from local to global governance. Restorat. Ecol. 25, 123-128. doi: $10.1111 / \mathrm{rec} .12388$

Vince, J., and Haward, M. (2017). Hybrid governance of aquaculture: opportunities and challenges. J. Environ. Manage. 201, 138-144. doi: 10.1016/j.jenvman.2017.06.039

Vince, J., and Stoett, P. (in press). From problem to crisis to interdisciplinary solutions: plastic marine debris. Mar. Policy. doi: 10.1016/j.marpol.2018.05.006

Vince, J., Brierley, E., Stevenson, S., and Dunstan, P. (2017). Ocean governance in the South Pacific region: progress and plans for action. Mar. Policy 79, 40-45. doi: 10.1016/j.marpol.2017.02.007

Wilcox, C., Mallos, N. J., Leonard, G. H., Rodriguez, A., and Hardesty, B. D. (2016). Using expert elicitation to estimate the impacts of plastic pollution on marine wildlife. Mar. Policy 65, 107-114. doi: 10.1016/j.marpol.2015. 10.014

Willis, K., Maureaud, C., Wilcox, C., and Hardesty, B. D. (in press). How successful are waste abatement campaigns and government policies at reducing plastic waste into the marine environment? Mar. Policy doi: 10.1016/j.marpol.2017.11.037

World Oceans Summit (2017). World Oceans Summit (Bali).

Worm, B. (2015). Silent spring in the ocean. Proc. Natl. Acad. Sci. U.S.A. 112, 11752-11753. doi: 10.1073/pnas.1513514112

Worm, B., Lotze, H. K., Jubinville, I., Wilcox, C., and Jambeck, J. (2017). Plastic as a persistent marine pollutant. Annu. Rev. Environ. Resour. 42, 1-26. doi: 10.1146/annurev-environ-102016-060700

Xanthos, D., and Walker, T. R. (2017). International policies to reduce plastic marine pollution from single-use plastics (plastic bags and microbeads): a review. Mar. Pollut. Bull. 118, 17-26. doi: 10.1016/j.marpolbul.2017. 02.048

Xinhuanet (2017). Kenya's waste Management Lobby Opposes Plastic Ban. Xinhuanet (Accessed 28 August 2017).

Conflict of Interest Statement: The authors declare that the research was conducted in the absence of any commercial or financial relationships that could be construed as a potential conflict of interest.

Copyright (c) 2018 Vince and Hardesty. This is an open-access article distributed under the terms of the Creative Commons Attribution License (CC BY). The use, distribution or reproduction in other forums is permitted, provided the original author(s) and the copyright owner are credited and that the original publication in this journal is cited, in accordance with accepted academic practice. No use, distribution or reproduction is permitted which does not comply with these terms. 